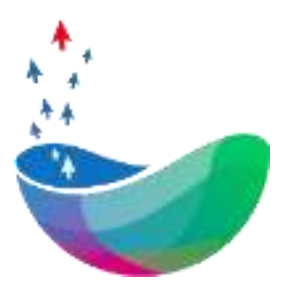

\title{
charity
}

\section{Peningkatan Pendapatan dan Perluasan Pangsa Pasar Melalui Digitalisasi Promosi Produk Hasil Olahan Nanas Masyarakat Petani Nanas di Jalancagak Kabupaten Subang} \author{
Romat Saragih ${ }^{5,}$ Suryana R. Achmad ${ }^{6}$, Ratna Gema Maulida ${ }^{7}$ \\ Program Studi Manajemen Pemasaran, Fakultas Ilmu Terepan, Universitas Telkom \\ Program Studi Manajemen Pemasaran, Fakultas Ilmu Terepan, Universitas Telkom \\ Program Studi Manajemen Pemasaran, Fakultas Ilmu Terepan, Universitas Telkom \\ Program Studi Administrasi Bisnis, Fakultas komunikasi Bisnis, Universitas Telkom \\ Program Studi Administrasi Bisnis, Fakultas komunikasi Bisnis, Universitas Telkom \\ Program Studi Manajemen Perhotelan, Fakultas Ilmu Terepan, Universitas Telkom \\ Program Studi Manajemen Perhotelan, Fakultas Ilmu Terepan, Universitas Telkom
}

Nellyaningsih 1. Ati Mustikasari ${ }^{2}$, Agus Maolana Hidayat ${ }^{3}$ Bachruddin Saleh Luturlean ${ }^{4}$

nellyaningsih@tass.telkomuniversity.ac.id

\section{INFO ARTIKEL}

Diterima 26 Juni 2019

Direvisi 3 Juli 2019

Disetujui 30 Agustus 2019

Tersedia Online 9 September 2019

\begin{abstract}
ABSTRAK
Salah satu nanas terbaik yang dihasilkan Indonesia bahkan diminati hingga pasar luar negeri berasal dari Subang yang dikenal dengan nama Nanas Madu. Selain buah Nanas, untuk menambah nilai ekonomis, UMKM di Jalancagak Kabupaten Subang mencoba membuat olahan berbahan dasar nanas diantaranya dodol, keripik, kue, dan lain-lain. Untuk kualitas dari produk yang mereka hasilkan sudah sangat baik, tetapi permasalahan yang mereka hadapi adalah belum maksimalnya penggunaan teknologi internet untuk kegiatan promosi, dan juga pemahaman mereka terhadap pembuatan laporan keuangan masih belum memadai dan juga kemasan. Sehingga tujuan dari kegiatan pengabdian masyarakat ini adalah melatih mereka untuk memaksimalkan teknologi internet sebagai media promosi dan meningkatkan pemahaman mereka dalam pembuatan laporan keuangan dan membantu membuatkan kemasan untuk buah nanas.

Adapun metode yang digunakan dalam kegiatan pengabdian masyarakat ini adalah memberikan pelatihan penggunaan teknologi internet seperti media social sebagai media promosi, pembuatan kemasan untuk buah nanas dan pelatihan pembuatan laporan keuangan.

Hasil yang dicapai pada pengabdian masyarakat di Jalan Cagak Kabupaten Subang adalah mereka sudah mampu menggunakan media social seperti Instagram, facebook, website sebagai media untuk mempromosikan produk-produknya, selain itu mereka juga sudah mampu membuat laporan keuangan sederhana yang dibutuhkan untuk mereka dalam menjalankan usahanya dan kemasan untuk buah nanas.
\end{abstract}


Keyword : $\quad$ Digitalisasi promosi, media sosial, kemasan

Korespondensi :

Direktorat Penelitian dan Pengabdian Masyarakat, Universitas Telkom

Jl. Telekomunikasi No. 1, Terusan Buah Batu, Bandung, 40257

Indonesia.

E-mail: charity@telkomuniversity.ac.id

ORCID ID: -

Penulis Pertama: Nellyaningsih

https://doi.org/10.25124/charity.v2i1.2068

Paper_reg_number 2068 ( ) The Authors. Published by Directorate of Research and Community Service, Telkom University.

This is an open access article under the CC BY-NC 4.0 license (https://creativecommons.org/licenses/by-nc/4.0/)

\section{PENDAHULUAN}

Subang dikenal sebagai salah satu sentra dari produksi nanas di Jawa Barat. Subang memiliki luas areal yang mencapai 2.100 hektar yang tersebar di lima kecamatan dan terluas berada di Kecamatan Jalan Cagak (sumber : ekbis.sindonews.com, 2018). Buah Nanas yang ditanam oleh para petani Subang mendapat julukan Nanas Madu karena terkenal dengan rasanya yang manis. Selain dari rasanya, keunggulan Nanas Subang juga karena buahnya berukuran besar, yaitu rata-rata 3 kilogram per buah. Bahkan ada buah yang beratnya mencapai 5 kilogram. Untuk dapat mengenali Nanas Subang, kita dapat melihat dari kulitnya, kulit Nanas Subang bermata buah datar, warnanya tetap hijau walaupun buahnya sudah matang selain itu daging buah berwarna putih hingga kuning pucat, berserat kasar, dan berair. Lembaga itu mencatat ada tiga kecamatan yang menjadi sentra nanas subang yakni Jalan Cagak, Cijambe, dan Cisalak.

Selain menghasilkan Nanas Madu, Subang juga punya beberapa olahan nanas diantaranya dodol nanas, keripik nanas, coklat nanas, kue/bolu nanas dan lain-lain. Untuk produk yang dihasilkan oleh UMKM di Jalancagak selain berbahan dasar nanas juga berbahan dasar singkong. Hampir semua olahan berbahan dasar Nanas ini memiliki rasa yang manis dan segar. Untuk olahan nanas beberapa produk masih merambah pasar lokal karena kegiatan promosi yang dilakukan masih bersifat konvensional seperti pemasaran melalui mulut ke mulut atau word of mouth, walaupun sudah terdapat beberapa produk yang selalu ikut dalam kegiatan-kegiatan pameran yang diselenggarakan oleh pemerintah. Peran serta pemerintah dalam kegiatan promosi berdampak pada perluasan pangsa pasar, dimana tidak hanya pasar dalam negeri tetapi juga sudah merambah hingga pasar luar negeri seperti Korea Selatan, Iran, Singapura dan Arab Saudi.

Tetapi untuk kegiatan promosi secara mandiri yang dilakukan oleh UMKM masih banyak yang dilakukan dengan cara konvensional, hal ini masih dilakukan oleh mereka bukan karena ketidakmampuan mereka dalam menggunakan teknologi internet ataupun smartphone, tetapi lebih disebabkan karena belum maksimalnya mereka dalam memanfaatkan teknologi ini untuk kegiatan promosi. selain itu dalam menjalankan usahanya, pengelolaan laporan keuangan mereka masih belum baik, sehingga mereka masih belum mengetahui dengan baik laba/rugi yang mereka hasilkan, modal yang mereka miliki dan lain sebagainya yang berkaitan dengan laporan keuangan. selain itu buah nanas sebagai salah satu ciri khas dari Subang belum memiliki kemasan untuk dapat meningkatkan nilai dari buah tersebut

Berdasarkan pemaparan diatas maka kegiatan pengabdian masyarakat yang kami lakukan adalah membantu mereka untuk mengoptimalkan pemanfaatan media internet sebagai media promosi yang bertujuan untuk meningkatkan pangsa pasar sehingga berdampak pada peningkatan pendapatan mereka dengan judul "Peningkatan Pendapatan dan Perluasan 


\section{Pangsa Pasar Melalui Digitalisasi Promosi Produk Hasil Olahan Nanas Masyarakat Petani Nanas di Jalancagak Kabupaten Subang"}

\section{MASALAH}

Berdasarkan hasil survey yang dilaksanakan oleh tim pengabdian masyarakat kepada masyarakat sasar, bahwa permasalahan yang dihadapi oleh masyarakat sasar berkaitan dengan kegiatan usaha olahan berbahan dasar Nanas yang dilaksanakan oleh UMKM di Jalancagak Kabupaten Subang adalah sebagai berikut :

1. Rendahnya Daya Saing dan Produk Tidak Memiliki Keunikan

Mereka menyebutkan bahwa produk yang mereka hasilkan masih berdaya saing rendah dibandingkan dengan pesaing produk sejenis karena produk yang mereka hasilkan belum memiliki keunikan yang menjadi ciri khas dari produk tersebut. Keunikan dari sebuah produk sangat penting karena menjadi kunci dalam memenangkan persaingan usaha baik itu berskala kecil, menengah, ataupun besar. Produk olahan berbahan dasar Nanas sudah banyak tersedia dipasaran oleh-oleh, sehingga dengan adanya keunikan maka konsumen dapat dengan mudah mengenali produk tersebut dan menjadi daya tarik tersendiri bagi konsumen. Dengan semakin mudahnya konsumen mengenali produk, maka semakin besar peluang produsen untuk menanamkan citra produk di benak konsumen.

2. Terbatasnya Pangsa Pasar

Keterbatasan pangsa pasar yang mereka hadapi karena kegiatan promosi yang mereka lakukan masih bersifat konvensional. Memperluas pangsa pasar sangat penting bagi keberlangsungan sebuah usaha, karena dengan memperluas pangsa pasar maka dapat dikatakan itu memperbesar usaha

3. Pengetahuan Pemanfaatan Teknologi Internet Rendah

Pengetahuan pemanfaatan teknologi internet khususnya media social ataupun web untuk kegiatan promosi dari para masyarakat sasar yang merupakan pelaku usaha yang menghasilkan produk olahan berbahan dasar nanas dapat dikatakan masih rendah. Sehingga mengakibatkan pangsa pasar mereka menjadi terbatas

4. Belum memiliki kemasan

Kemasan merupakan salah satu bagian terpenting dari suatu produk. Dengan adanya kemasan pada sebuah produk, hal ini dapat menjadi nilai tambah bagi produk mereka. Dimana nilai tambah ini dapat menjadi keuntungan bagi mereka (UMKM)

\section{METODE KEGIATAN}

\subsection{Metode Kegiatan Pengabdian}

Berdasarkan Solusi Dan Target Luaran dari rencana pelaksanaan program PKM pada kedua mitra yang telah ditetapkan, maka tim menetapkan metode pendekatan sebagai berikut :

A. Metode Pelatihan Metode pelatihan, ditujukan untuk mentrasfer Ilmu pengetahuan dan teknologi (Ipteks) dalam mengatasi permasalahan melalui peningkatkan wawasan, pemahaman bagi mitra. Yang mana pelaksanaan pelatihan direncanakan dilaksanakan dalam satu ruangan di Balai desa atau kecamatan. Adapun metode pendekatan ini ditetapkan oleh tim untuk mengatasi permasalahan, dan solusi mencapai target luaran yang telah ditetapkan yaitu pelatihan penggunaan media social sebagai media promosi, pelatihan pembuatan laporan keuangan dan kemasan

B. Metode Bimbingan Teknis dan Pendampingan Metode Pendekatan ini, ditujukan untuk mentrasfer ipteks, agar kedua mitra mampu mempraktekan hasil dari pendekatan pelatihan dengan Bimbingan Teknis dan Pendampingan dari pakarnya (tim), dimana metode 
pendekatan ini di laksanakan langsung di lapangan(masing - masing tempat Mitra). Pakar/Tim bertindak secara aplikatif untuk mengarahkan, membimbing proses dan tahapan, memberi contoh, kepada Mitra dalam mengatasi permasalah dan mencapai target dan luaran dari pelatihan penggunaan media social sebagai media promosi, pelatihan pembuatan laporan keuangan dan kemasan

C. Metode Pendekatan Fasilitasi dan Media Metode pendekatan ini, ditujukan untuk mempermudah, meringankan, memperlancar, menghubungkan, membuatkan (mendesain), mendapatkan, dan memiliki sesuatu yang dibutuhkan oleh mitra. Pendekatan Fasilitasi dan mediasi bagi mitra ini digunakan dalam mengatasi permasalah dan mencapai target dan luaran sebagai berikut :

1. Fasilitasi dan mediasi fasilitasi akses terhadap klien/calon pelanggan dan mediasi kemitraan usaha

2. Membuatkan (mendesain) media promosi Website dan kemasan

3. Pelatihan pembuatan laporan keuangan

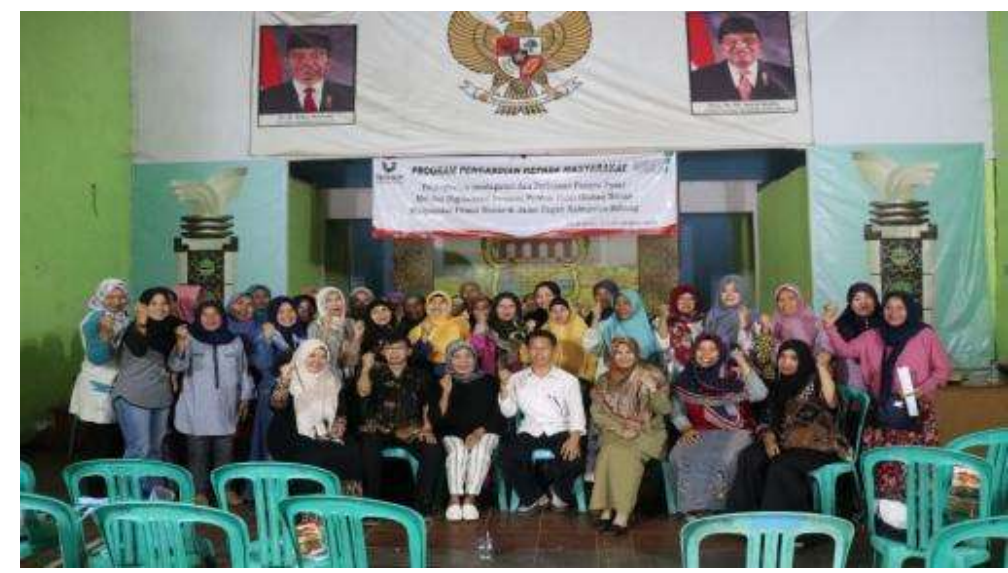

Gambar 1 Kegiatan di Pelatihan Sumber: Dokumentasi pribadi

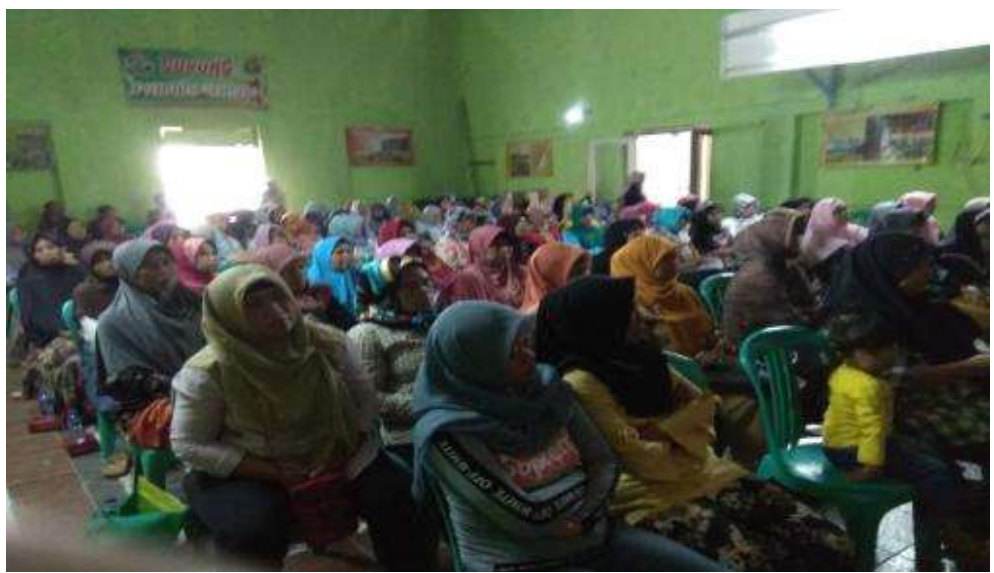

Gambar 2 Kegiatan di Pelatihan

Sumber : Dokumentasi pribadi 


\subsection{Teknik Pengumpulan Data}

Teknik Pengambilan data berupa pertanyaan dari survey, wawancara dan observasi.

\subsection{Teknik Analisis Data}

Deskriptif kuantitatif adalah teknik analisis data yang dilakukan yang bertujuan untuk mendapatkan gambaran karakteristik penduduk dan kondisi perekonomian masyarakat.

\subsection{Lokasi, Waktu, dan Durasi Kegiatan}

Kegiatan akan dilaksanakan di balai pertemuan desa jalancagak kabupaten Subang, Jawa Barat mulai tanggal 27 April 2019 hingga 29 April 2019.

\section{ANALISA HASIL KEGIATAN}

Hasil Luaran dari pengabdian masyakat sesuai dengan kegiatan pelatiahn yang kami laksanakan antara lain:

1. Mitra dapat menghasilkan berbagai jenis produk baru dengan model, corak, dan kombinasi produk sesuai tuntutan pasar.

2. Mitra memahami cara membuat merk produk dan kedua mitra memiliki merk produk sendiri

3. Mitra memiliki dokumen tertulis sebagai pedoman dalam menjalankan usaha yang menggambarkan secara menyeluruh dan sistematis aspek - aspek usahanya

4. Mitra memiliki media promosi Online

5. Mitra memiliki kemasan untuk produk nanas

\subsection{Kegiatan}

Produk olahan nanas tersebut pada awalnya dikemas melalui kemasan plastik dan diberikan kertas label sebagai identitas produk. Seiring dengan berjalannya usaha, mitra berencana untuk menyasar pasar ritel sebagai jalur distribusi produk. Dengan landasan perubahan jalur dstribusi tersebut, maka diperlukan proses redesign kemasan produk olahan nanas agar bisa bersaing dengan produk lainnya. Berdasarkan paparan pada paragraf sebelumnya, tim dosen dari Universitas Telkom melalui program pengabdian kepada masyarakat memberikan pengetahuan kepada para masyarakat desa tambakan kabupaten subang mengenai peningkatan kualitas produk. Dimana, salah satu materi tersebut mengenai pentingnya kemasan dalam peningkatan mutu suatu produk.

Pada program pengabdian kepada masyarakat tersebut, tim dosen juga membuat proto type kemasan produk olahan nanas

\section{Proses perancangan kemasan produk olahan nanas.}

\section{a. Penentuan material kemasan}

Mengingat adanya kebutuhan dari produk makanan olahan nanas dalam hal ini pie nanas yang akan meningkatkan jalur distibusinya kearah ritel, maka langkah yang pertama dilakukan dalam proses perancangan ialah mencari beberapa reverensi visual dari produk yang sudah dijual di pasar ritel. Dalam hal ini, fokus yang ditujukan ialah mencari material yang baik dalam melindungi produk sekaligus mampu memberikan nilai estetis ketika produk di tampilkan pada suatu rak. 


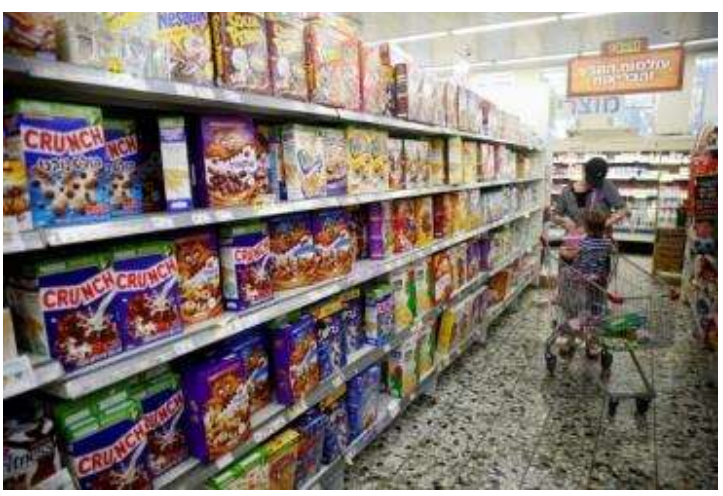

Gambar 3 Kemasan produk yang telah ditampilkan pada suatu rak display

Sumber gambar: https ://www.republika.co.i d/berita/gaya-hi dup/tips/17/08/16/our5ps382-daftar-bar ang-yangsebaiknya-tidak-dibeli-di-supermarket diakses pada: 11 april 2019 pukul: 08.30

Mengingat banyaknya material bahan yang digunakan sebagai kemasan, maka diputuskan material kertas yang akan digunakan sebagai kemasan dari makanan olahan nanas (pie nanas) dan kemasan buah nanas. Pemilihan kertas sebagai material dikarenakan kemudahannya untuk memberikan tampilan visual berupa image maupun elemen grafis lainnya dan banyaknya akses keberbagai percetakan kertas yang sudah banyak tersebar di berbagai kota.

\section{b. Analisis kompetitor sebagai reverensi visual}

Setelah menentukan material kemasan, maka langkah selanjutnya ialah menganalisis beberapa kemasan kompetitor sehingga dapat ditentukan key visual baik warna maupun image yang telah digunakan serta sudah difahami oleh masyarakat umum.

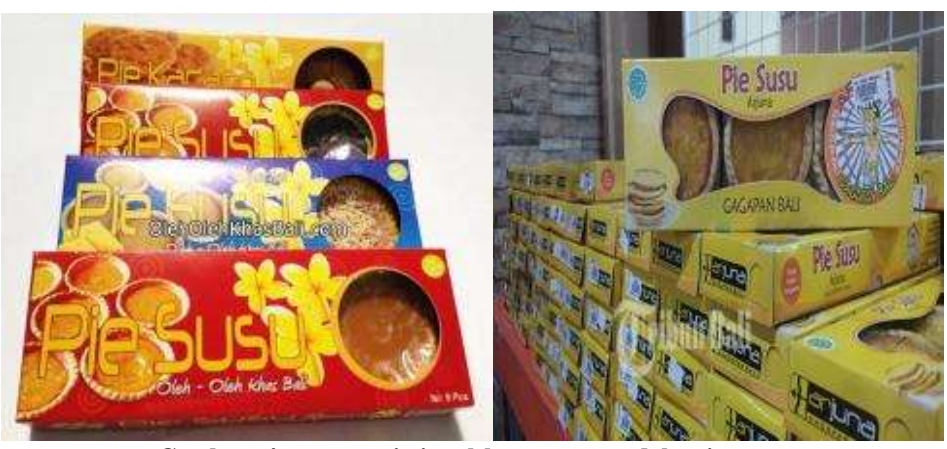

Gambar 4. reverensi visual kemasan produk pie susu

Setelah melihat dari beberapa kemasan produk kompetitor, maka didapat beberapa key visual yang dapat dibawa ke proses peracangan, antara lain:

1. Penggunaan warna hijau dan kuning yang dominan

2. Penggunaan elemen visual dari tumbuhan nanas yang cukup dominan, baik dari daun, pohon, maupun buah.

\section{c. Perancangan kemasan produk olahan nanas.}

Berdasarkan pada key visual yang telah disebutkan pada pembahasan sebelumya, maka proses desain diawali dengan pembuatan sketsa dengan tema buah nanas. Proses sketsa diawali dengan sketsa manual dan dilanjutkan dengan proses digitalisasi melalui software grafis berbasis vector.

Key visual yang telah terbentuk secara digital selanjutnya akan dirangkai sebagai background kemasan yang berperan sebagai tekstur untuk meningkatkan aspek emosi pada kemasan tersebut. Mengingat material yang digunakan ialah kertas, maka pembuatan pola 
kemasan merupakan hal yang dilakukan. Dimana pola kemasan ini selanjutnya akan dilakukan proses pelipatan sehingga menghasilkan bentuk tiga dimensi dari bentukan box persegi
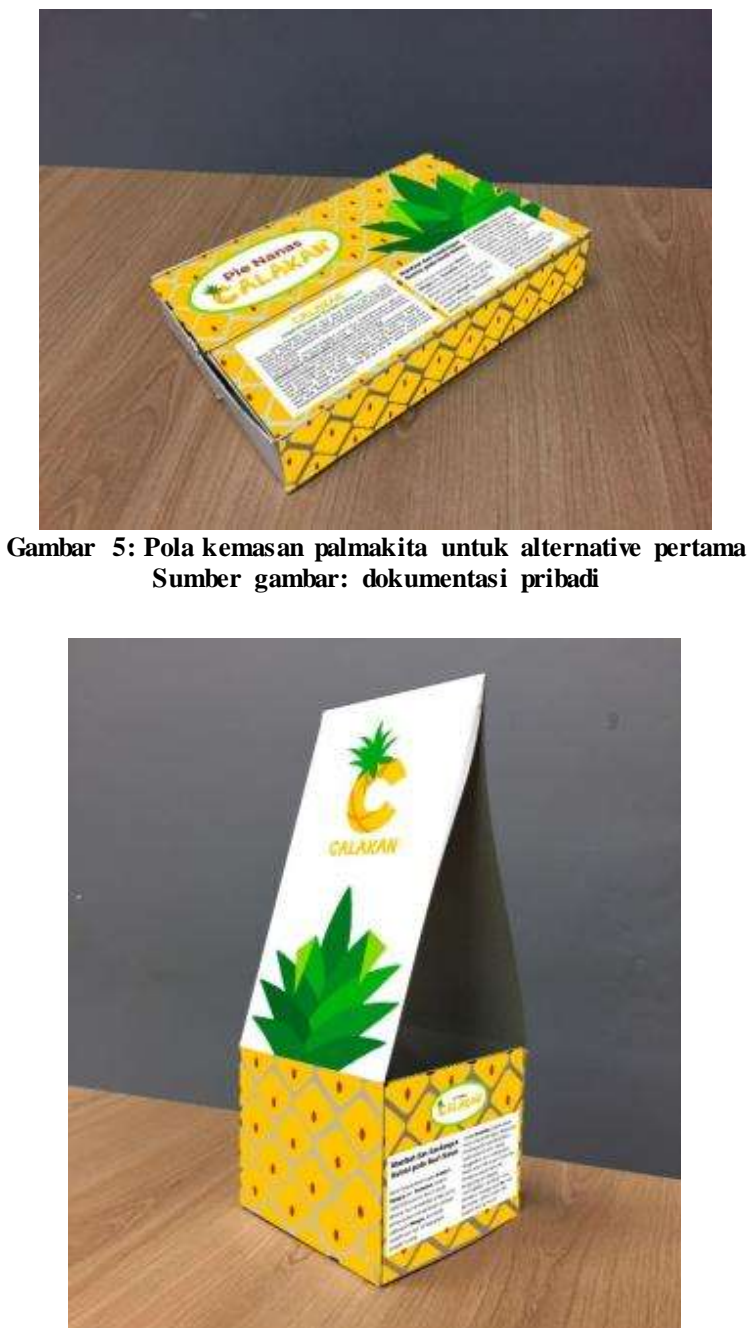

Gambar 6: Pola kemasan palmakita untuk alternative kedua Sumber gambar: dokumentasi pribadi

Secara warna, kemasan yang dirancang mengedepankan warna kuning sebagai warna dominannya untuk menggambarkan sifat alami dan nilai sehat yang dimiliki oleh produk tersebut. Selain dari itu, penggunaan huruf sanserif ditujukan untuk membuat visualisasi desain yang terkesan lebih modern. Sedangkan informasi mengenai produk seperti halal, produksi, dan lain-lain, disebar di beberapa area pada kemasan, baik pada bagian depan, samping kanan dan kiri, maupun pada bagian belakang.

\section{DAFTAR PUSTAKA}

https://ekbis.sindonews.com/read/1366519/34/kementan-dorong-kemitraan-dan-hili risasinanas-subang-1546022895

\section{LAMPIRAN KEGIATAN}



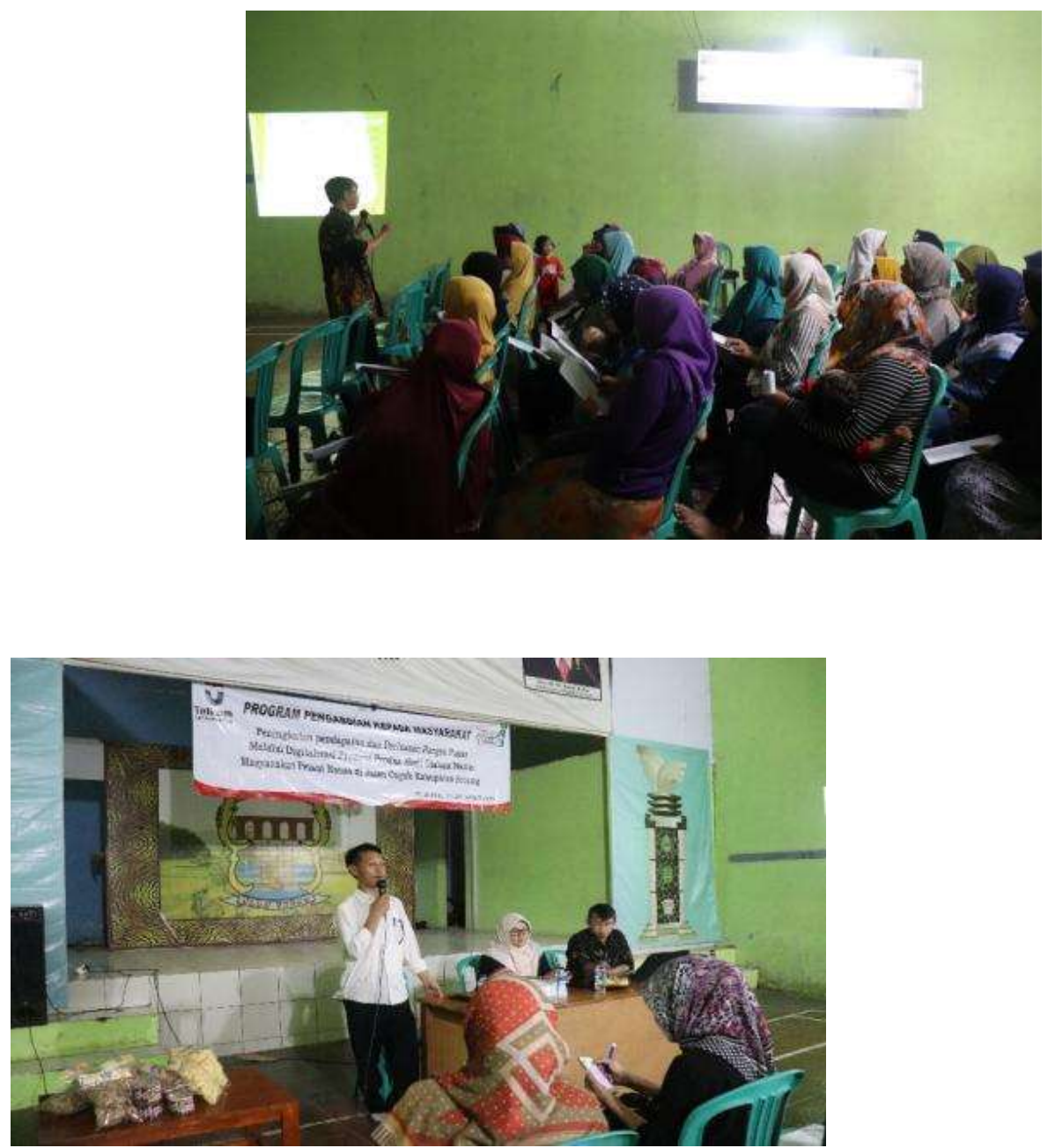